\title{
RESEARCH
}

Open Access

\section{Praxis pedagogy in teacher education}

\author{
Julie Arnold ${ }^{1 *}$ and Brian Mundy ${ }^{2}$
}

\author{
* Correspondence: julie.arnold@ \\ deakin.edu.au \\ ${ }^{1}$ Faculty of Arts and Education, \\ Deakin University, Melbourne, \\ Australia \\ Full list of author information is \\ available at the end of the article
}

\begin{abstract}
This paper presents and analyses a pedagogical model which focuses on 'praxis'. Portfolio dialogue, case writing and signature pedagogy mapping are all identified as central to this model. These pedagogical practices intend to create a possibility of orientation rather than a lineal hierarchy of outcomes for pre-service teachers. Part of this paper reports on data received from final year preservice teachers regarding their portfolio discussions and considers the presence and the contributions of the signature pedagogies. New knowledge concerning planning of practice through visual modes may assist staff and students via critical, dialogical and a praxis views within teacher education.

Keywords: Praxis, Signature pedagogies, Teacher education, Transformative
\end{abstract}

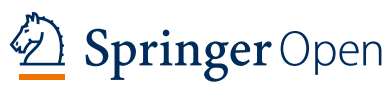

\section{Introduction}

A model for teacher education has been developed by the College of Education. It is a distinctive model which draws on 8 signature pedagogies to initiate animated and dynamic conversations between preservice teachers and lecturer. These conversations are rightfully shaped by experiences of practice and centre on many 'real' concerns, issues and interests and demand highly relevant responses and deep reflection by academics and preservice teachers. This paper although part of a broader theoretical discussion, provides a more pragmatic / practical view of a praxis model of pedagogy in teacher education and has developed at a time when there is a need to review ideas and some broad agenda that currently exist in Australian teacher education policy and processes.

This study responds to the considerations of the Australian context in teacher education and to provide a voice for an informed and rigorous teaching pedagogy in teacher education. The current Australian Institute for Teaching and School Leadership (AITSL) proposal is to shape and reform initial teacher education (ITE) through such strategies as standards and selection processes, partnerships and high quality courses. A Teacher Education Ministerial Advisory Group (TEMAG) identified imperatives for ITE courses and was the basis of a response by the Australian Government in 2015. The Victorian State minister also addressed the issue in a publication titled 'Working together to shape teacher education in Victoria: a discussion paper' (Merlino, 2016). These documents have since confirmed and paved the way for reforms in teacher education for Victorian education providers. This research highlights the need for teacher education providers to provide evidence and commitment to models and impact of innovative pedagogy for preservice teachers.

(c) The Author(s). 2020 Open Access This article is distributed under the terms of the Creative Commons Attribution 4.0 International License (http://creativecommons.org/licenses/by/4.0/), which permits unrestricted use, distribution, and reproduction in any medium, provided you give appropriate credit to the original author(s) and the source, provide a link to the Creative Commons license, and indicate if changes were made. 
Immersing preservice teachers in schools combined with a praxis inquiry model of learning enables preservice teachers to make explicit links between practice and theory. By definition praxis pedagogy is derived from context and 'concrete structures' (Freire, 1972, p. 36). This research explores pragmatic and reflective processes. Researching the impact of models to evidence best practice for students, preservice teachers, teachers and university educators is essential if we are to respond to the challenges we face as global learning for citizens in the twenty-first century.

The praxis model relies heavily on linking theory and practice. It is a complex process that captures the unique experience of the preservice teacher (Burridge, Carpenter, Cherednichenko, \& Kruger, 2010) which is often underrepresented in ITE experience for those studying to become a teacher (Biggs \& Tang, 2007; Tang, 2003). Praxis by nature involves deep exploration of pedagogical experiences and theory to critique practice (Arnold, Edwards, Hooley, \& Williams, 2012).

A praxis model has been developed and supported by 8 signature pedagogies that make up an approach and focuses on praxis pedagogy which includes a portfolio dialogue connecting professional practice, repertoires of practice, teachers as researchers, participatory action research, case conferencing, community partnerships and praxis learning (Arnold et al., 2014; Arnold, Edwards, Hooley, \& Williams, 2013). When inquiry stems from practice then preservice teachers begin questioning - 'The class $I$ took didn't go well today. Was it something I did?' These types of conversations and indeed a praxis pedagogy are powerful modes for transformative (Kalantzis, 2006) learning in teacher education. In this paper there is an attempt to dig deeper to explore what the pedagogies look like in terms of the practical experiences for preservice teachers. Many protocols and pedagogies are implemented and identified in the institution and Table 1 (Hooley, 2015, p. 168) below indicates a number of these praxis approaches and characteristics adopted for the preservice teachers for consideration when tackling issues and improvements in their professional practice.

The Signature Pedagogies are based on a balanced repertoire of Praxis Pedagogies and were developed through examination of the types of pedagogies implemented in undergraduate and postgraduate learning in the College of Education. Not only does this table map the characteristics of practice that account for thinking critically about preservice teacher education, it also supports teaching, learning and research for lecturers and preservice teachers through practice. Centred on practice, these pedagogies act as tools for interrogating their work. Table 1 above developed by Hooley (2014) identifies elements of common pedagogies which have been adopted and frequently implemented within the College of Education. Characteristics of praxis pedagogy while nested in the Signature Pedagogies are elaborated on in Fig. 1. Figure 1 below highlights the complexity of essential characteristics that we find in teacher education to prepare 'transformative' preservice teachers, teachers, learners and researchers.

These characteristics are process focussed and utilised by both students and lecturers. They help to connect practice to theory and theory to practice. Experiences of practice provide a platform in teacher education for preservice teachers to begin to examine and develop practice that is rigorous, ethical and critical. This research has developed through a reflexive and collaborative process through ongoing dialogue and conversations regarding accounts of practice and theorising with colleagues at Victoria 
Table 1 Signature Pedagogies

\begin{tabular}{|c|c|c|c|}
\hline \multirow{2}{*}{$\begin{array}{l}\text { Signature Pedagogies } \\
\text { Professional Practice } \\
\text { (Schatzki, Kemmis, } \\
\text { Green) }\end{array}$} & \multicolumn{3}{|c|}{ Characteristics of signature pedagogies } \\
\hline & $\begin{array}{l}\text { Recognises personal } \\
\text { learning from immersion } \\
\text { in practice }\end{array}$ & $\begin{array}{l}\text { Supports communities of } \\
\text { practice to support inquiry } \\
\text { for improved learning } \\
\text { environments and student } \\
\text { learning }\end{array}$ & $\begin{array}{l}\text { Continuing critique of } \\
\text { practice for change of } \\
\text { conditions to formulate } \\
\text { ideas of new practice }\end{array}$ \\
\hline $\begin{array}{l}\text { Repertoires of } \\
\text { practice (Kalantzis, } \\
\text { Cope) }\end{array}$ & $\begin{array}{l}\text { Identifies and articulates } \\
\text { features of pedagogical, } \\
\text { curriculum, assessment } \\
\text { practices }\end{array}$ & $\begin{array}{l}\text { Links key features of } \\
\text { pedagogy, curriculum, } \\
\text { assessment for change } \\
\text { and improvement }\end{array}$ & $\begin{array}{l}\text { Critiques repertories of } \\
\text { educational practice as } \\
\text { social activity that supports } \\
\text { satisfaction and progress }\end{array}$ \\
\hline $\begin{array}{l}\text { Teacher as Researcher } \\
\text { (Stenhouse) }\end{array}$ & $\begin{array}{l}\text { Systematically investigates } \\
\text { own practice for } \\
\text { improvement }\end{array}$ & $\begin{array}{l}\text { Participates as member } \\
\text { of school-based research } \\
\text { team } / \mathrm{s}\end{array}$ & $\begin{array}{l}\text { Relates local, national and } \\
\text { global research, policy and } \\
\text { practice }\end{array}$ \\
\hline $\begin{array}{l}\text { Case Conferencing } \\
\text { (Shulman) }\end{array}$ & $\begin{array}{l}\text { Generates case and } \\
\text { commentary writing for } \\
\text { understanding of practice }\end{array}$ & $\begin{array}{l}\text { Participates in case } \\
\text { conferencing and concept } \\
\text { analysis for production of } \\
\text { teachers' knowledge }\end{array}$ & $\begin{array}{l}\text { Encourages articulation } \\
\text { and analysis of teachers' } \\
\text { knowledge in relation to } \\
\text { theories of curriculum } \\
\text { and teaching }\end{array}$ \\
\hline $\begin{array}{l}\text { Community } \\
\text { Partnership (Gonzalez, } \\
\text { Moll \& Amanti; Sizer) }\end{array}$ & $\begin{array}{l}\text { Connects with local } \\
\text { communities }\end{array}$ & $\begin{array}{l}\text { Integrates community } \\
\text { culture and knowledge } \\
\text { into curriculum }\end{array}$ & $\begin{array}{l}\text { Investigates community to } \\
\text { understand local aspiration, } \\
\text { history, knowledge, language }\end{array}$ \\
\hline $\begin{array}{l}\text { Praxis Learning } \\
\text { (Freire) }\end{array}$ & $\begin{array}{l}\text { Investigates / provides } \\
\text { description, explanation, } \\
\text { theorising and change of } \\
\text { practice in response to } \\
\text { reflection on practice }\end{array}$ & $\begin{array}{l}\text { Demonstrates a curriculum } \\
\text { developed from praxis and } \\
\text { in response to refection }\end{array}$ & $\begin{array}{l}\text { Constructs learning } \\
\text { environments of ethically- } \\
\text { informed action for the } \\
\text { public good }\end{array}$ \\
\hline $\begin{array}{l}\text { Participatory Action } \\
\text { Research (Kemmis) }\end{array}$ & $\begin{array}{l}\text { Identifies and advocates } \\
\text { key issues of policy and } \\
\text { participates in collecting } \\
\text { data for analysis }\end{array}$ & $\begin{array}{l}\text { Contributes to project } \\
\text { discourses with internal and } \\
\text { external team members }\end{array}$ & $\begin{array}{l}\text { Theorises and critiques } \\
\text { research findings in the } \\
\text { public domain }\end{array}$ \\
\hline $\begin{array}{l}\text { Portfolio Dialogue } \\
\text { (Freire, Dewey, } \\
\text { Brookfield) }\end{array}$ & $\begin{array}{l}\text { Compiles and discusses } \\
\text { artefacts of personal } \\
\text { learning over time }\end{array}$ & $\begin{array}{l}\text { Participates with artefact and } \\
\text { knowledge discourses that } \\
\text { show understandings of } \\
\text { meanings of practice }\end{array}$ & $\begin{array}{l}\text { Demonstrates a coherent } \\
\text { philosophy consistent with } \\
\text { personalised practice and } \\
\text { community change for } \\
\text { public good }\end{array}$ \\
\hline
\end{tabular}

University, and also colleagues concerned with similar ideas and views on teacher education from national and international settings.

Critical to these signature pedagogies is the role of dialogue and this occurs through the implementation of learning circles. Figure 2 exposes further dialogue that is enacted and the value of learning circles and signifying deeper practical and visual elements of the praxis mapping and model (Kress, 2010; van Leeuwen, 2005).

\section{Literature review}

The underlying shift to the model of signature pedagogies indicated has relied on a dialogic approach to learning and knowledge (Freire, 1989) and experiences from classrooms of preservice teachers (Dewey, 1938). The opportunity of envisaging 'transformative' curriculum, approaches and outcomes for students (Arnold et al., 2012; Arnold et al., 2014; Hooley, 2013; Kalantzis, 2006) underpins the conversations when presenting cases and the portfolio. It is during conversations that practice is described, explained, theorised and re-imagined. Portfolios based on signature pedagogies are developed by the preservice teachers as a basis for the praxis to encompass ideas of pedagogical perspectives in terms of current and future professional engagement. Collegiate 

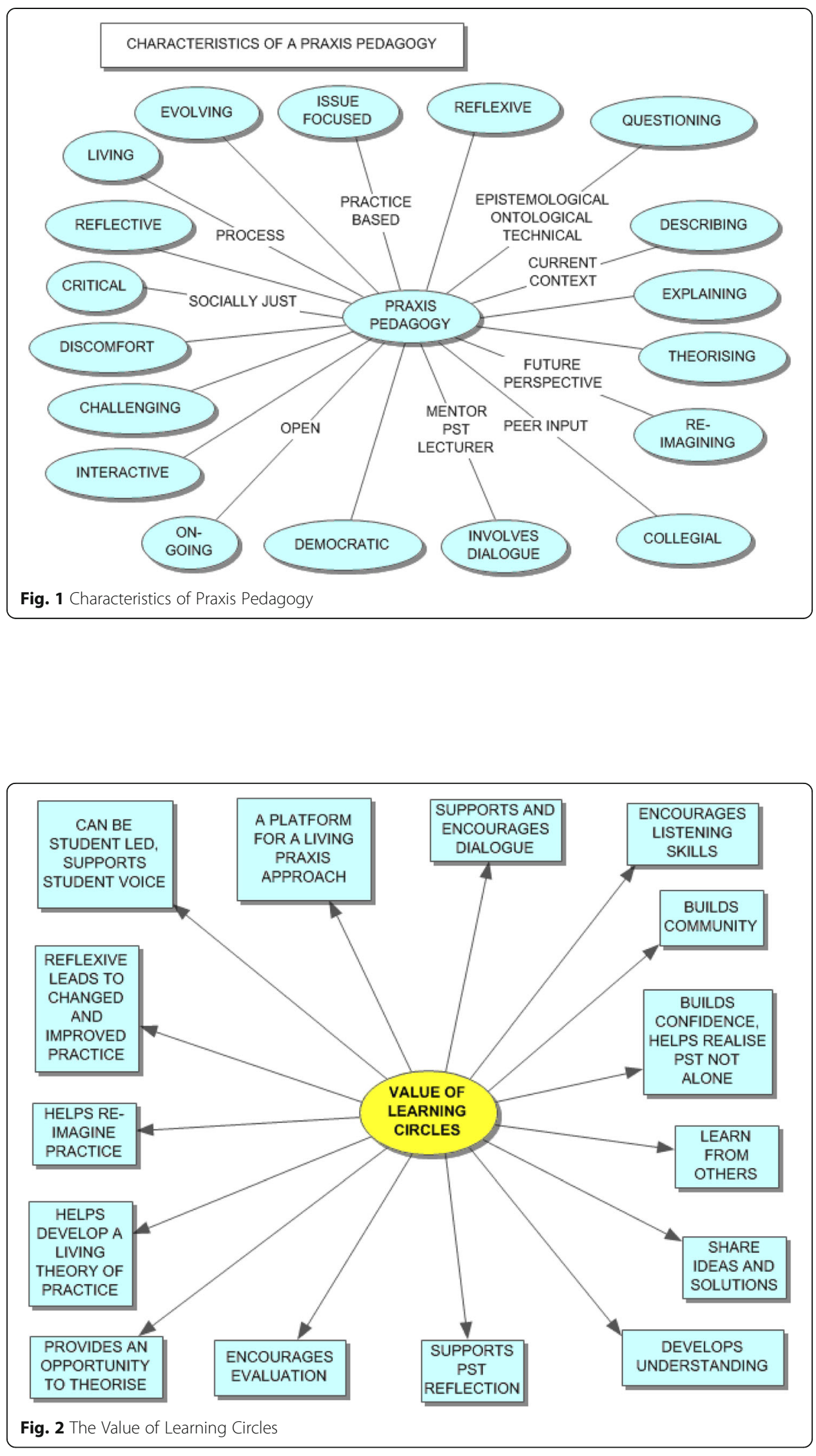
conversations often include perspectives of the preservice teacher, mentor teachers and lecturer and can be enhanced through 'Learning Circles' (Fitzgerald, Farstad, \& Deemer, 2005, p. 212; Peters \& Le Cornu, 2005), case writing and commentary (Cherednichenko, Hooley, Kruger, \& Mulraney, 1997) processes as ways of enabling this type of dialogue. When preservice teachers are able to articulate their own inquiry (Loughran, 2006; Shulman, 1992) and position, there is an opportunity for critical dialogue (Freire, 1989) which is based on real issues from teaching and learning experience to become highly focused, thoughtful and critical (Arnold et al., 2012; Green, 2009). Preservice teachers bring highly developed ideas and ways of knowing that reflect habitus (Bourdieu, 1977), Frames of Reference (Burridge et al., 2016), Funds of knowledge (Moll, Amanti, Neff, \& Gonzales, 1992) and experiences (Dewey, 1938). 12.

The qualitative method includes narrative data (Riessman, 2008) and provides dialogue (Clandinin \& Connelly, 1990) from the preservice teachers' perspectives that described understanding of the conditions of teaching and learning and the importance of making connections to theories and practice in the classroom. This research whilst acknowledging the progressive scholarly critiques and approaches also focuses on knowledge, expertise and prior learning that students bring to their chosen field of teaching as a 4th year student in teacher education.

Accessing preservice teacher notions of cultural values, capabilities and 'funds of knowledge' which form and inform preservice teacher's learning should not be overlooked in teacher education. Human and social experiences are bound by sociopolitical and cultural agency (Gonzales, Moll, \& Amanti, 2005). For preservice teachers examining one's own pedagogy may be one way of reflecting on the virtues of why and how we teach. The ability for preservice teachers to critique is crucial. Praxis pedagogy provides the opportunities for educational issues to be shared and explored deeply enabling preservice teachers to reflect on the practice of schools and the curriculum. It is important to not understate the personal funds of knowledge which preservice teachers bring that is deep and highly personalised (Bourdieu, 1976; Moll et al., 1992).

To further validate the praxis model, a group of colleagues from the College of Education routinely met to provide educational perspectives to develop a strong theoretical foundation. The Signature Pedagogies are underpinned by many theorists and some examples of these authors are provided in the rubric. It is important to identify here the authors which underpin the Signature Pedagogies. Teacher education requires accounts of Professional Practice (Green, 2009; Kalantzis, 2006; Kemmis, 2012; Schatzki, 2001) which provides a foundation for teachers to engage in and consider behaviours to improve and think critically about practice. Building a culture of Teacher as Researcher (Stenhouse, 1985) is an expectation which embodies the manner in which teachers gather data about their students and respond to the data through practice. Stephen Brookfield (1995) considers development of portfolios by teachers as an effective reflective tool and a means to document processes for improving practice. Not only does Brookfield suggest a rationale for such a practice, but also presents a variety of ways in which portfolios may be documented. These practices might include reflective approaches such as Case writing (Shulman, 1992) accounts of experiences and inquiries into practice. Portfolios become useful ways of documenting learning in teacher education and have traditionally explored teachers' work as well as a way of considering critical practice by presenting challenging dilemmas and issues from everyday teaching 
and learning experiences in the classroom. Kalantzis and Cope (2000) are introduced as a theoretical foundation for highlighting Repertoires of Practice and in particular those associated with new literacies and technological developments in the classrooms. They suggest cultural shifts and the increasing expectations of teacher and learner approaches are often confronting practices. Critical theory as indicated by Moll et al. (1992) suggest considering funds of knowledge as a way for teachers to critically examine perceptions of collective, communities and knowledge exchange. Freire (1989) emphasises dialogue and praxis as a form of exposing symbiotic processes and a way of moving towards thinking critically.

\section{Signature pedagogies - a discussion}

This study utilises data from 4th year preservice teachers to consolidate and evaluate on the merits of the Signature Pedagogies. The reviews of the Signature Pedagogical approaches along with experiences and accounts of practice prompted lively discussions by preservice teachers and the response indicated a critical understanding. These connections continued increasingly recognised by preservice teacher and lecturers in effectively meeting the Australian Standards (VIT and AITSL) during classes and particularly during portfolio presentations. Analysis of these accounts is further explored in the method of this research. Signature Pedagogies have developed as a result of the theoretical foundations outlined and ideas have merged to distinguish approaches that reveal elements of 'trustworthiness' in the development of preservice teacher within the College of Education. The approaches implemented along with the focus of the data collection are outlined in the following commentary.

\section{Methodology}

The methodology focuses on some of the commentary and personal accounts from preservice teachers which contributed to the data collection process. Small group forums were held to discuss the features of the Signature Pedagogies. Pedagogical tools and approaches are required when thinking about praxis. These praxis tools provide an approach and provide a mechanism for a critical approach to understanding. Preservice teachers from Victoria University in their 4th year of study of the Bachelor of Education (Prep - Year 12) were invited to participate in the research project. Data was gathered from a random selection of 25 year 4 preservice teachers. Preservice teachers were briefed on the research and if interested were invited to provide accounts and respond to the Signature Pedagogy rubric as a way of mapping their practice. This was completed by each individual preservice teacher in groups of 5. Data was collected and following this work conversations to debrief and revisit the purpose of the study were implemented. Data was analysed and themes drawn to exemplify connections from practice and praxis. Engaging 25 preservice teachers in early discussions on aspects of the Signature Pedagogies through the rubric listed as Table 1 (Hooley, 2014) provided a basis for identifying practices within their teaching and learning experiences. A combination of approaches is useful to enable the analysis of the development of preservice teacher professional practice and praxis. The Signature Pedagogies have been critical in determining the impact of professional experience and the process of linking theory and practice. 
Many preservice teachers approached this mapping in a variety of ways. The instructions were clear and acted as a general guide by which they could begin to map their development. The instructions given to preservice teachers included

- Identify your thinking in terms of considering the ideas from the rubric

- Indicate the use of the rubric as a way of monitoring practice

- Tell us what you think of this model at this early stage

- Find the appropriate pedagogy/ies which reflect/s the way in which you teach, learn and research

- Indicate why you have made your choices and how is it located in your practice

Although this data required a mapping activity by preservice teachers, it was a qualitative methodology. This process was not to be a comprehensive audit or checklist, but to indicate and explain the appropriate pedagogies that were used when thinking about professional experience. Preservice teachers did not have difficulty indicating what worked for them and carefully considered their choice and were quickly able to identify examples of practice. For example, one preservice teacher wrote about the features of the rubric, '... prompts deeper thinking and reflection on professional practice. An authentic look at the process as opposed to content driven.' Sue (preservice teacher).

A qualitative methodology enabled a close exploration of 4th year preservice teacher pedagogical praxis. To explore praxis, preservice teachers were invited to participate in forums and conversations regarding their practice. All students were briefed as to the purpose of the project and those who chose to be involved were provided detailed information and consent forms were then provided. The ethical practices were clarified and preservice teachers were reassured privacy would be protected and they could withdraw from the research if they chose without any penalty (Singh, Reid, Mayer, \& Santoro, 2011). Once these ethical considerations as required higher education institution were in place focus group discussions were held with participants regarding their evaluation of the Signature Pedagogy rubric and artefacts. It will be made clear that such discussions are completely unrelated to assessment requirements. Focusing on portfolios (Brookfield, 1995; Cochran-Smith \& Lytle, 2009; Zeichner \& Wray, 2001) and the opportunity for inquiry into practice offers an inclusive approach for preservice teachers particularly in their final year of study. Portfolios are not new to teacher education, but when used as a research tool whereby stories, cases and commentaries and evidence contribute critical dialogue they provide valuable pedagogical conversations when shared with colleagues. When engaging with preservice teachers, time is given to dialogue and for us, 'the research portfolio seems to open dialogue in a practical way for those candidates who have struggles with the idea of making teacher research a logical part of their practice'. Cases (Shulman, 1992) are included as part of the preservice teacher research of practice and bring meaning and insights from elements of classroom experiences. The process of case writing is well suited to teacher education and provides opportunity to share practice and commentary through inclusive protocols. The idea of case writing encourages critical perspectives that provide a platform for shared new knowledge based on the connected and 'lived experience' (Clandinin \& Connelly, 1990) of those involved. 


\section{Data}

Data was gathered and has been derived from 10 preservice teachers and included both male and female from the Bachelor of Education (P-12) course at Victoria University during 2014. Small case studies provide details for considering a way in which preservice teachers might approach the signature pedagogies framework. These accounts of small case studies lead the research and through examining and analysing critical conversations and written commentaries for preservice teachers we gain perspectives of their ability to identify their own understanding. The insights vary in description and understandings when approaching the 8 signature pedagogy rubric. The range of feedback has been useful in determining the next step of developing and embedding the model in the curriculum. Preservice teachers self-selected to be involved in the process of utilising the signature pedagogy map for their own appraisal and reflection. An overview of the rubric and signature pedagogies was discussed to a point in order to become familiar with many of the key terms. The preservice teachers were asked semi structure questions such as

- What do the students think of the rubric? Is it appropriate to the preservice teacher experience?

- Can they recognise their work? What can they recognise?

- Are the terms in the rubric appropriate and do they reflect your work during the units /course?

- What are your general opinions on this rubric?

Responses and feedback from preservice teachers provided an overview for the researchers of the complex conversations. Taking these conversations further we then indicated to the preservice teachers to

- Identify yourself

- Indicate the use of the rubric as a way of monitoring practice

- Find pedagogies and indicate how they might be located in your practice?

We were particularly interested in what the preservice teachers thought of the model at this early stage. The responses were surprising and rich discussion arose and lapsed into a number of critical and collaborative conversations concerning such things as Participatory Action research, Community partnerships and Praxis Learning. Portfolios, Case writing, Learning circles and Praxis Inquiry protocols were discussed by some preservice teachers as a basis for dialogue on the Signature Pedagogies.

These conversations became the highlight of the new ground on which we were moving. This paper signifies how data sourced conversations from the small case studies that pressed preservice teachers to contemplate connections with language, pedagogies and beliefs. With this map, preservice teachers contemplated new space for reflecting on praxis with university peers, colleagues and internalising these ideas through processes of intersubjectivity (Biesta, 1998; Mead, 1939) and reflexive practices. 


\section{Defining and presenting the model through preservice teacher praxis}

The signature pedagogy model is intricately bound to practice. Presenting some of the early ideas and initial impacts of distinctive praxis for a teacher education model requires that we view ways in which praxis and critical reflection is implemented to the improvement and practice in teacher education and student outcomes. This presentation draws out characteristics of the model.

Questioning, describing, explaining, connecting, case writing and bringing values, lived experience, moral commitment to improving the human condition and imagining new perspectives are some practices that demonstrate what teacher education requires. An initial definition of praxis pedagogy has also been proposed. For us praxis pedagogy is defined as, student centred, critical thinking, which includes an ethical perspective and with a future aim of improving student outcomes.

This definition and the accompanying diagrams raise questions and intend to respond to further ideas of a dialogic and interactive praxis in an ethical space and where education is seen as a democratic process and human virtue valued. Figure 3 below demonstrates how praxis pedagogy as defined operates in the classroom.

\section{Analysis}

When discussing the Signature Pedagogies rubric with preservice teachers they provided stories or accounts of practice to illustrate and identify particular pedagogies.

When Rosie (preservice teacher) was presenting her portfolio, she provided a story about an experience on school placement. The story was prompted by 'a reluctance to read from some of the students' from her class. After writing a case regarding this concern, she developed a critical commentary with others she indicated that the case and commentary protocol pedagogy 'encourages analysis of teachers' knowledge in relation to theories of curriculum and teaching'. She had reflected on the Signature Pedagogy map in a way that enabled her to articulate and identify a way for her to search and

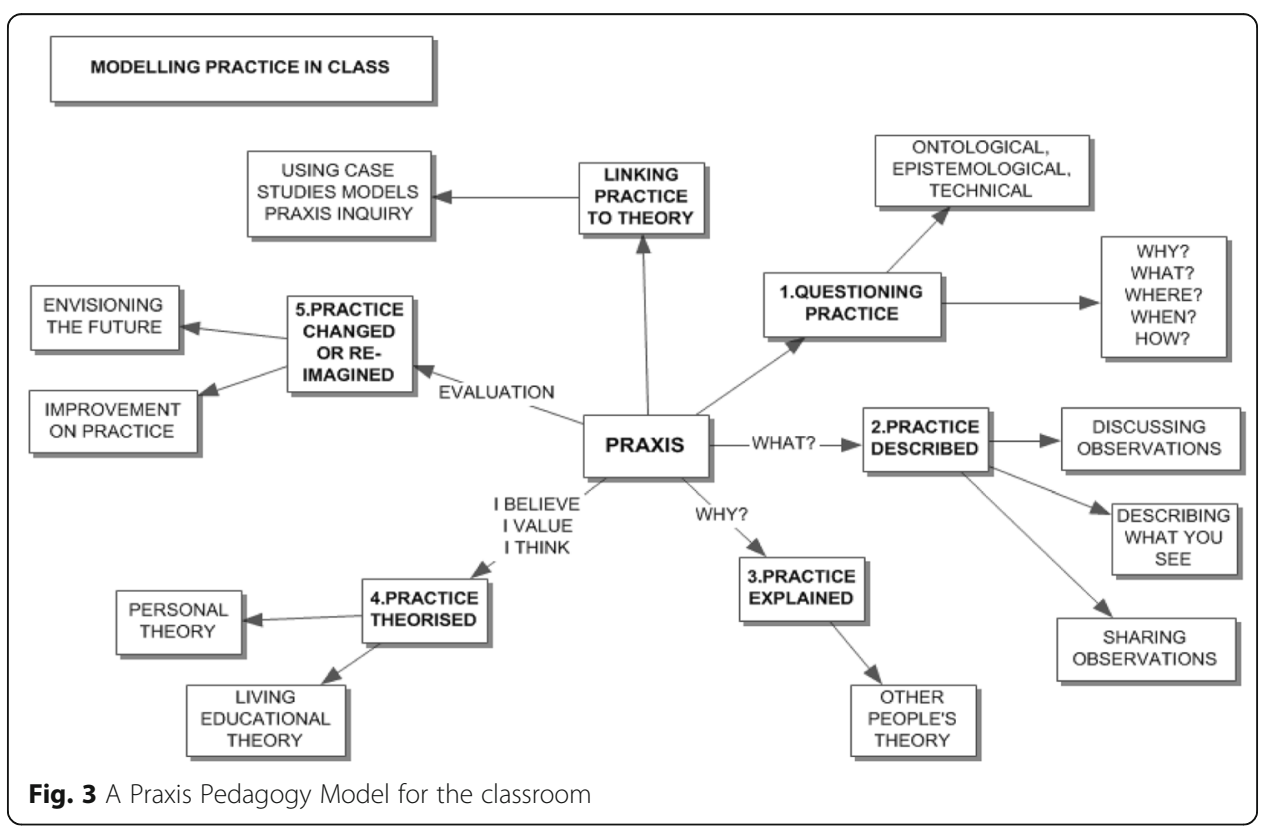


research the concern she had with her reluctant readers. She then came up with a plan. She indicated she would attempt to solve this issue in her classroom by implementing a 'dot' chart for students to determine their own reading behaviours in an individual learning plan. She added, 'I think the pedagogies rubric makes you think deeper about the concepts. I think it makes you reflect better on what you have learnt and the type of teacher you want to be.' Rosie (preservice teacher).

When Linda (preservice teacher) was articulating and positioning her practices she chose three areas from the Signature Pedagogies rubric to make comment on. Like Rosie, she began with Case conferencing. Linda also chose to discuss Praxis Learning (inquiry into her practice) and Participatory Action research. Table 2 below indicates the three Signature Pedagogies determined by Linda for explaining her practice.

Linda presented many accounts of her practice, but did not immediately recognise these within the Signature Pedagogies rubric. For instance, Linda described the focus and structure of the school she was currently placed in. She felt the school has a strong sense of community and the curriculum had a strong integrated curriculum. Linda was engaging and she did this by providing a story - a story told of her practice. She began by articulating that the sense of community within the school had prompted her to tell her story to the students. She chose a literacy lesson to write her story for the students during the beginning of the writing session. A literacy practice and understanding pedagogy that was engaging, contextualised and relevant and which highlighted the Signature Pedagogy of Community and Partnership characteristic titled 'Integrates community culture and knowledge into curriculum'. After this conversation and reflection, Linda was able to locate her practice and praxis pedagogy in the Signature Pedagogy rubric.

Elizabeth (preservice teacher) began with some early comments after viewing the Signature Pedagogies map for some time and stated, 'Some of the language seems to just be there for the sake of it - this does not get used in the day-to-day setting.' This critique draws attention to when and why the use professional language and the social practices teachers and researcher engage in. Adopting and adapting to social and professional practice requires a growth mindset (Dweck, 2006). In general preservice teachers grapple with language used in teacher education programs. It is not until the preservice teachers join the profession that there is a 'sobering understanding' (Cochran-Smith et al. p. 111) and professional shift from university- based experience. Elizabeth indicated she would like 'more case writing'. This is a constructive comment and an indication of her professional mindshift and growth. Continuing critique of practice for change of conditions to formulate ideas of new practice is indicated under the title of Professional Practice in the Signature Pedagogies. There is evidence to suggest that

Table 2 Linda's praxis learning

\begin{tabular}{|c|c|c|}
\hline \multicolumn{3}{|l|}{ Signature Pedagogies } \\
\hline Pedagogy & Explanation of pedagogy & Preservice teacher comment \\
\hline Case Conferencing & $\begin{array}{l}\text { Generates case and commentary } \\
\text { writing for understanding practice }\end{array}$ & $\begin{array}{l}\text { 'Using an inquiry model for case writing really } \\
\text { helped me understand my practice better' }\end{array}$ \\
\hline Praxis Learning & $\begin{array}{l}\text { Develops curriculum and cress- } \\
\text { curriculum praxis approaches } \\
\text { to learning }\end{array}$ & $\begin{array}{l}\text { 'This was visible in my Integrated Studies } \\
\text { approaches and detailed in my portfolio' }\end{array}$ \\
\hline Participatory Action research & $\begin{array}{l}\text { Contributes to project discourses } \\
\text { with internal and external learning } \\
\text { members }\end{array}$ & $\begin{array}{l}\text { 'This was done on a daily basis with staff } \\
\text { and uni classmates in a school applied } \\
\text { curriculum project' }\end{array}$ \\
\hline
\end{tabular}


Elizabeth is reflecting on the challenges she may find in the classroom and recognising that perhaps case writing may assist her to address the professional social practices she may encounter in her future work. Elizabeth also discussed the Applied Curriculum Project (ACP) she was engaged in at her school stating, 'The ACP went well - it needed to be more school directed to really address their [school] needs'. She indicated that this particular pedagogy was also connected to the opportunity to 'Participate as member of school-based research team/s.' An ACP provides opportunity for preservice teachers negotiate with the school to collaborate on a school research project. These projects require that the team design, gather data and analyse data for the benefit of school and student outcomes. Elizabeth's enthusiasm is evident when speaking about the ACP and this dialogue and exchange regarding the Signature Pedagogies resulted in recognising herself as a participant in a research team and 'Teacher as researcher'. She added that the ACP had a middle years' focus and discussions in the university classes assisted and in particular, Case Conferencing was important for developing the ACP.

These responses along with many others not included in this paper, indicated to us that students were thinking about the ideas and articulating from experience from which to theorise. Their perspectives provided a stance for developing practice.

Figures 1, 2 and 3 indicate the connections drawn as a result of our reflections from the data (preservice teachers' stories) and the processes occurring in the classroom. This provided a way of connecting the theorising of the preservice teachers and the processes linked to their praxis. We find these diagrams useful for exploring the characteristics of praxis pedagogy. They illustrate the rationale and processes that can occur in praxis pedagogy.

\section{Conclusion}

This paper aimed to provide a pragmatic view of a praxis model in the area of praxis pedagogy in teacher education. A framework was presented and outlined consisting of 8 signature pedagogies as a model for the reader to consider. This model has been critical in the development and reviewing of preservice teachers' practical work and has gained support to suggest that this focuses on praxis pedagogy is worthy in teacher education and indicated in Table 3.

The 8 signature pedagogies embedded in the praxis model act to connect closely theory and practice supporting preservice teachers in developing their own pedagogies and educational theories of practice and understanding. Preservice teachers gave their ideas with an open-handed and unbiased critique of the Signature Pedagogies while consistently connecting to their own practice. The 8 signature pedagogies act to connect closely theory and practice supporting pre-service teachers in developing their own pedagogies and educational theories of practice (Whitehead, 1993). A definition of pedagogy in teacher education requires consideration of what relevant practice and approaches in preservice teachers' professional experience may look like in the higher education settings. We recognise the need for shift in teacher education. Attention to the way in which teacher educators and researchers reflect on their work is useful to developing high performing preservice teachers. At a time when teacher education is under scrutiny there is an imperative to focus on appropriate and embedded pedagogical approaches if teacher education is to produce critical and well prepared teachers. The proposed praxis pedagogy offers a powerful and insightful way forward. While political pressures and public debate suggest that raising teacher standards is important (Merlino, 2016; Singh et al., 2011) this study presents a method for consideration. 


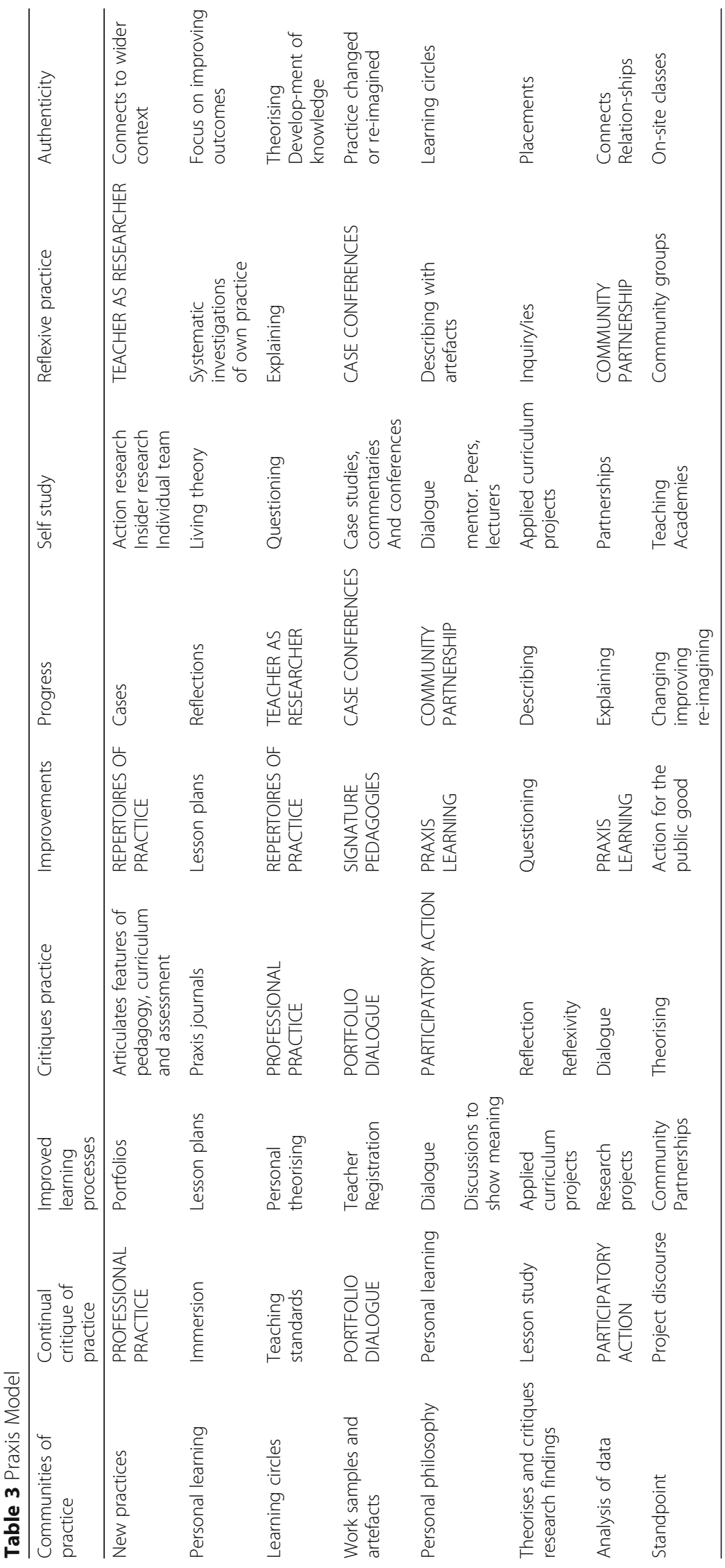




\section{Acknowledgements}

There is acknowledgement to those who contributed to the article.

\section{Authors' contributions}

$J A$ and BM participated in the sequencing and alignment of the drafted and final manuscript. JA and BM participated in the review of the analysis and synthesis of the manuscript. JA carried out the interviews. BM and JA selected the key points from the interviews for the finals draft. BM created the praxis models in fir 1, 2 and 3. JA created the Table 3. All authors have read and approved the final manuscript.

\section{Funding}

No funding body was involved in the design, data collection, analysis, interpretation or manuscript writing or manuscript writing services.

\section{Ethics approval and consent to participate}

Ethics processes were sought and approved and data / data set access is not able to be shared publically as this condition was included in the ethics application and approval.

\section{Competing interests}

The authors declare that they have no competing interests.

\section{Author details}

${ }^{1}$ Faculty of Arts and Education, Deakin University, Melbourne, Australia. ${ }^{2}$ College of Arts and Education, Victoria University, Melbourne, Australia.

Received: 12 November 2019 Accepted: 31 January 2020

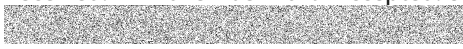

\section{References}

Arnold, J., Burridge, P., Cacciattolo, M., Cara, C., Edwards, T., Hooley, N., \& Neal, G. (2014). Researching the signature pedagogies of praxis teacher education. Brisbane: AARE -NZARE.

Arnold, J., Edwards, A., Hooley, P., \& Williams, J. (2013). Site-based teacher education for enhanced community knowledge and culture: Creating the conditions for 'philosophical project knowledge'. Aust. Educ. Res., 40(1), 61-75.

Arnold, J., Edwards, T., Hooley, N., \& Williams, J. (2012). Conceptualising teacher education and research as "critical praxis". Critical Studies in Education, 53(3), 281-295.

Australian Government Department of Education and Training, 2015 Action now: classroom ready teachers report. Teacher Education Ministerial Advisory Group - Australian Government released on 13 February 2015 https:/www.studentsfirst. gov.au/teacher-education-ministerial-advisory-group

Biesta, G. J. (1998). Mead, Intersubjectivity, and education, the early writings. In Studies in Philosophy and Education (Vol. 17, pp. 73-99). Utrecht: Kluwer Academic Publishers.

Biggs, J., \& Tang, C. (2007). Teaching for quality learning at university, what the student does. In Society for Research into Higher Education (3rd ed.). Berkshire: Open University Press McGraw-Hill Education.

Bourdieu, P. (1976). The school as a conservative force: Scholastic and cultural inequities. In R. Dale, G. Esland, \& M. MacDonald (Eds.), Schooling and Capitalism (pp. 110-117). London: Routledge.

Brookfield, S. (1995). Becoming a professional practitioner. San Francisco: Jossey-Bass.

Burridge, P., Carpenter, C., Cherednichenko, B., \& Kruger, T. (2010). Investigating praxis inquiry within teacher education using Giddens' structuration theory. Journal of Experiential Education, 33, 19-37 http://journals.sagepub.com/doi/abs/10.1177/1 05382591003300103.

Burridge, P., Hooley, N \& Neal, G. 2016. Creating frames of practice for teacher education. Asia-Pacific Journal of Teacher Education, 42(2), 156-17, https://doi.org/10.1080/1359866X2015.1041877.

Cherednichenko, B., Hooley, N., Kruger, A., \& Mulraney, R. (1997). The practice of beginning teachers: Identifying competence through case writing in teacher education. Australian Journal of Teacher Education, 22(2). https://doi.org/10.14221/ajte. 1997v22n2.3 Accessed 19 Aug 2015.

Clandinin, D. J., \& Connelly, F. M. (1990). Stories of experience and narrative inquiry. Educational Researcher, 19(5), 2-14 American Educational Research Association, USA. http://www.jstor.org/stable/1176100.

Cochran-Smith, M., \& Lytle, S. L. (2009). Inquiry as stance: Practitioner research in the next generation. New York: Teachers College Press.

Dewey. (1938). Experience and education, Kappa Delta Pi Lecture Series. New York: Collier Books.

Dweck, C. (2006). Mindset: The new psychology of success. London: Random House.

Fitzgerald, L. M., Farstad, J., \& Deemer, D. (2005). In Loughran \& Russell (Ed.), Improving Teacher Education Practice Through Self Study. New York: Routledge.

Freire, P. (1972). Cultural action for freedom. Ringwood: Penguin.

Freire, P. (1989). Education for the Critical Consciousness. New York: Continuum.

Gonzales, N., Moll, L. C., \& Amanti, C. (Eds.). (2005). Funds of knowledge: Theorizing practices in households, communities and classrooms. Mahwah: Lawrence Erlbaum Associates.

Green, B. (2009). Understanding and researching professional practice. In Professional Learning (pp. 1-18). Rotterdam: Sense Publications.

Hooley, N. (2013). Exposing the intricacies of pre-service teacher education: Incorporating the insights of Freire and Bourdieu. Review of Education, 1(2), 125-158.

Hooley, N. (2015). Learning at the practice Interface: Reconstructing dialogue for progressive educational change. New York: Routledge. 
Kalantzis, M. (2006). Elements of a science of education. The Australian Educational Researcher, 33(2), 15-42 The Netherlands: Springer.

Kalantzis, M., \& Cope, B. (2000). Changing the role of schools. In B. Cope \& M. Kalantzis (Eds.), For the New London group, multiliteracies: Literacy learning and the design of social futures (pp. 121-148). London and New York: Routledge.

Kemmis, S. (2012). Researching educational praxis: Spectator and participant perspectives. British Educational Research Journal, 38(6), 885-905 UK

Kress, G. (2010). Multimodality: A social semiotic approach to contemporary communication. London: Routledge.

Loughran, J. (2006). Developing a pedagogy of teacher education: Understanding teaching and learning about teaching. New York: Routledge.

Mead, GH. (1939). The Philosophy of the Act, Ed. Introduction by CW. Morris et al. Chicago: University of Chicago Press.

Merlino, J. (2016). Working together to shape teacher education in Victoria: A discussion paper, Victoria State Government, http://www.education.vic.gov.au/Documents/workingtogether.pdf

Moll, L. C., Amanti, D., Neff, N., \& Gonzales, N. (1992). Funds of Knowledge for Teaching: Using a Qualitative Approach to connect homes and classrooms. Theory into Practice, 31, 132-141 UK: Taylor and Francis Ltd.

Peters, J., \& Le Cornu, R. (2005). Beyond communities of practice: Learning circles for transformational school leadership, chapter 6 in Carden and Stehlik. In Beyond Communities of Practice. Queensland: Post Press.

Riessman, C. (2008). Narrative methods for human sciences. Los Angeles: Sage.

Schatzki, T. R (2001). Practice minded orders, In T.R. Schatzki, K.K. Cetina \& E.V. Savigny (Eds). The practice turn in contemporary theory, 42-55. Abingdon: Routledge.

Shulman, J. H. (1992). Teacher-written cases with commentaries: A teacher-researcher collaboration. In J. Shulman (Ed.), Case methods in teacher education (pp. 131-152). New York: Teachers College Press.

Singh, M., Reid, J., Mayer, D., \& Santoro, N. (2011). Forming, informing and transforming teacher education researchers as ethical subjects. Asia-Pacific Journal of Teacher Education, 39(4), 281-291. https://doi.org/10.1080/1359866X.2011.615115.

Stenhouse, L. (1985). Research as a basis for teaching' in Rudduck, J and Hopkins, D 1985, research as a basis for teaching readings from the work of Lawrence Stenhouse. London: Heinemann Educational Books Ltd..

Tang, S. Y. F. (2003). Challenge and support: The dynamics of student teachers' professional learning in the field experience. Teaching and Teacher Education, 19, 483-498.

Van Leeuwen, T. (2005). Introducing social semiotics. London: Routledge.

Whitehead, J. (1993). The growth of educational knowledge: Creating your own living educational theories. Bournemouth: Hyde. Zeichner, K. \& Wray, S. (2001). The teaching portfolio in US teacher education programs: What we know and what we need to know. Teaching and Teacher Education, 17(5), 613-612 Elsevier Ltd.

\section{Publisher's Note}

Springer Nature remains neutral with regard to jurisdictional claims in published maps and institutional affiliations.

\section{Submit your manuscript to a SpringerOpen ${ }^{\circ}$ journal and benefit from:}

- Convenient online submission

- Rigorous peer review

- Open access: articles freely available online

High visibility within the field

- Retaining the copyright to your article

Submit your next manuscript at $\boldsymbol{\nabla}$ springeropen.com 